\title{
EFEKTIFITAS DAKWAH DALAM \\ MENGEMBANGKAN KOGNITIF-FUNGSIONAL AUDIENS:Suatu Pendekatan Psikologi Sosial
}

\author{
Muhammad Alim Ihsan \\ STAIN Datokarama Palu, Jl. Diponegoro 23 Palu \\ e-mail:alim_ihsan@yahoo.com
}

\section{Abstract}

Islamic propagation ( $\left.d a^{\prime} w a h\right)$ can be regarded as effective if it is accepted by wider audiences and leads to fundamental changes of their religious attitude and behavior. At the individual level, it is refelected in the extent to which audiences undergo basic changes in their understanding of the core of Islamic teaching such as belief, ethics, worship and social relations. At the social level, it is reflected in a social milieu in which Islamic values illuminate social intercourse between communities.

$$
\begin{aligned}
& \text { إن فعالية الدعوة إلى الله تعالى بشأن ترشيد الدعوة إليه يمكن قبولها لدى } \\
& \text { المستمعين الذين يحوزون الرغبة الأكيدة فى تغير المبدأ و السلوك الدينى }
\end{aligned}
$$

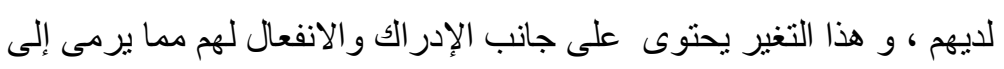

$$
\begin{aligned}
& \text { الأهداف المنشودة لدى المكلفين بالدعوة إلى الله ، و فى هذا نتمثل فعالية } \\
& \text { الدعوة فى أى مدى تفهم أفر اد مجتمع الدعوة لقيم العقبدة و الثريعة (التى هى } \\
& \text { الاخلاق و العبادة و المعاملة) و هما بمثابة نواة الدين الإسلامى ، و على } \\
& \text { مستوى حياتهم الاجتماعية تتمثل فعالية الدعوة فى أوضاعهم الاجتماعية و و } \\
& \text { التى هى تعظم شعائر الإسلام ، بل و قد تمنزج نواميس حياتهم هذه بالقيم } \\
& \text { الإسلامية الغراء التى يحرصون عليها. }
\end{aligned}
$$

Kata Kunci: efektifitas dakwah, metode dakwah, kognisi, emosi, audiens 


\section{PENDAHULUAN}

Tatanan baru kehidupan dunia dewasa ini telah membawa pengaruh yang signifikan dalam kehidupan umat manusia. Pola interaksi kehidupan manusia semakin dipercaya oleh berbagai corak budaya, pemikiran dan konsepsi dasar mengenai makna kehidupan itu sendiri, tanpa mengenal batas ruang dan waktu. Era globalisasi seakan-akan telah menyatukan umat manusia di jagad raya ini dalam suatu "desa kecil" yang tidak lagi mengenal batas-batas geografi.

Perubahan-perubahan di atas di samping membawa berbagai manfaat dan kemudahan, juga menggandeng akibat-akibat destruktif. Salah satu bentuk dari akibat destruktif tersebut adalah bergesernya orientasi hidup manusia dari yang bersifat material-ateistik. Manusia semakin jauh dari tujuan hidup yang sebenarnya.

Persoalannya kemudian adalah bagaimana upaya-upaya dakwah Islam untuk menangani persoalan yang cukup krusial ini, sebab dakwah adalah usaha manusia untuk mengajak umat manusia agar masuk ke dalam sistem Islam atau jalan Allah. Karena dakwah berfungsi sebagai pemandu moral perjalanan hidup umat manusia maka sangat dibutuhkan peranannya dalam menata kehidupan manusia yang lebih anggun berdasarkan ajaran Islam.

Upaya untuk mencapai misi dakwah tersebut di atas bukan pekerjaan yang sederhana. Dakwah Islam berhadapan dengan kompleksitas peradaban penemuan-penemuan baru dalam bidang ilmu pengetahuan dan teknologi yang telah membawa pengaruh yang besar terhadap cara berpikir kritis dan rasional. Manusia sekarang tidak percaya terhadap sesuatu yang belum jelas kebenarannya. Untuk mempengaruhi seseorang di zaman sekarang haruslah didukung oleh alasan yang argumentatif dan bukti-bukti yang nyata tentang informasi atau pesan dakwah yang disampaikan.

Sebenarnya dalam diri manusia terdapat potensi kognisi dan emosi yang jika mampu dikembangkan secara baik dan benar akan mampu mengarahkan manusia dalam tindakan - tindakannya.Oleh larena itu, perlu dirancang metode dakwah yang tepat untuk menumbuhkan kedua potensi tersebut. Tidak semua metode cocok 
untuk setiap audiens yang akan menerima pesan-pesan dakwah. Untuk itu, perlu dirumuskan metode dakwah yang efektif dalam rangka mempengaruhi audiens agar bersedia menerima, menghayati, dan mengamalkan ajaran-ajaran Islam sebagai inti dari pesan-pesan dakwah tersebut. Efektifitas dakwah dapat dilihat dari dua sisi, yaitu pesan diterima atau tidak oleh objek dakwah. Jika dakwah diterima, auidiens akan melakukan perubahan perilaku keagamaan. Perubahan perilaku tersebut meliputi dua aspek, yaitu kognisi dan emosi audiens yang mengarah dan mendekati tujuan yang ingin dicapai oleh dakwah tersebut. Efektifitas dakwah tercermin pada sejauh mana objek pada dawkah pada tingkat individu mengalami perubahan yang benar dan makin lengkap pemahamannya terhadap akidah, akhlak, ibadah, dan mu'amalah sebagai inti ajaran Islam. Pada tingkat tatanan sosial (masyarakat), efektifitas dakwah tercermin pada iklim sosial yang makin memancarkan syi'ar Islam dan makin mendekatknya norma sosial pada nilai-nilai Islam dan aturan hidup bermasyarakat menurut ajaran Islam.

Dengan demikian, efektifitas dakwah menyangkut efektifitas dan efisiensi, sampai tidaknya pesan dakwah kepada audiens. Dalam hal ini, masalah dakwah berkaitan dengan metode dan materi yang sesuai dengan kondisi objektif audiens.

Untuk mengembangkan kognisi dan emosi audiens, diperlukan metode dan materi dakwah yang tepat. Hal inilah yang mendorong penulis berusaha merumuskan secara konsepsional dan operasional mengenai efektifitas dakwah dalam mengembangkan kognisi dan emosi audiens.

\section{DAKWAH DAN PEGEMBANGAN KOGNISI DAN EMOSI AUDIENS}

\section{Pengertian Dakwah}

Untuk menemukan bangunan pemikiran yang tepat mengenai dakwah, maka perlu dijelaskan pengertian dakwah, baik secara etimologis maupun terminologis.

Ditinjau dari segi etimologis, kata "dakwah" berasal dari bahasa Arab yang berarti: panggilan, ajakan, dan seruan. Secara 
terminologis, dakwah mengandung pengertian segala aktivitas yang bertujuan untuk mensosialisikan dan mengaktualisasikan ajaran Islam.

Para pakar dakwah memberikan berbagai interpretasi mengenai dakwah Islam. Hasjmy menyebutkan bahwa dakwah islamiah adalah mengajak orang lain untuk meyakini dan mengamalkan akidah dan syari'at Islam yang terlebih dahulu telah diyakini dan diamalkan oleh pendakwah sendiri (Hasjmy, 1994:7). Dalam pengertian dakwah, terdapat dua sudut pandang, yaitu pembinaan dan pengembangan. Dakwah dalam arti pembinaan, yaitu usaha untuk mempertahankan, melestarikan, dan menyempurnakan umat manusia dalam agar mereka tetap beriman kepada Allah, dengan menjalankan syariatNya sehingga mereka menjadi manusia yang hidup bahagia di dunia dan akhirat, sedangkan dalam arti pengembangan, dakwah berarti usaha mengajak umat manusia yang belum beriman kepada Allah swt. agar mentaati syariat Islam (memeluk agama Islam) supaya nantinya dapat hidup bahagia dan sejahtera, baik di dunia maupun di akhirat (Syukur, 1983:20).

\section{Pengertian Kognisi}

Dalam buku Kamus Besar Bahasa Indonesia disebutkan bahwa kognisi mengandung pengertian kegiatan atau proses memperoleh pengetahuan atau usaha mengenali sesuatu melalui pengalaman sendiri (Pusat Bimbingan dan Pengembangan Bahasa, 1995:5811). Kognisi ini memiliki pengertian yang terkait erat dengan istilah intelegensi sebab intelegensi berarti daya reaksi atau penyesuaian yang cepat dan tepat, baik secara fisik maupun mental, terhadap pengalaman-pengalaman baru, membuat pengalaman dan pengetahuan yang dimiliki siap untuk dipakai apabila dihadapkan pada fakta-fakta atau kondisi-kondisi baru. Hal ini menggambarkan kecerdasan individu.

Dalam struktur tubuh manusia ada yang disebut dengan otak, dan eksistensi otak tersebut adalah untuk berpikir. Secara sederhana, otak yang difungsikan secara baik dan benar ini disebut dengan berpikir. Berpikir secara sederhana sebagai gejala jiwa dapat 
menetapkan hubungan-hubungan antara pengetahuan yang pernah di alami selama ini. Secara sistematis pendapat ahli mengatakan bahwa berpikir itu dapat dikelompokkan ke dalam dua eksistensi, yaitu: Pertama, bahwa berpikir itu adalah aktivitas, jadi bukan subjek yang berpikir aktif; dan kedua, berpikir itu sifatnya ideasional, jadi bukan sensoris dan motoris, walaupun dapat disertai oleh kedua hal itu. Berpikir itu menggunakan abstraksi-abstraksi atau ide (Hasan, 1994:38).

Proses kognisi merupakan kondisi internal individu. Perhatian merupakan salah satu proses kognitif di samping persepsi, latihan, memberi simbol dan penilaian. Indra ingatan merupakan alat penyimpan informasi. Informasi yang disimpan oleh ingatan dari lingkungan sangat menentukan langkah selanjutnya. Mengingat berarti menyerap dan meletakkan pengetahuan dengan jalan mencamkan secara aktif. Ada beberapa fungsi ingatan, yaitu: menangkap dan menerima kesan-kesan, menyimpang dan memproduksi kesan-kesan.

Ingatan yang baik adalah yang siap dan cepat serta kuat dan luas. Kuat dan luas berlaku dalam menyimpan, sedangkan siap berlaku dalam memproduksi kesan-kesan. Ingatan cepat maksudnya adalah apabila dalam menentukan kesan-kesan itu tidak mengalami kesulitan. Ingatan kuat akan memiliki kapasitas menyimpan informasi dalam waktu yang lama, sedangkan ingatan yang luas adalah ingatan yang mampu menyimpang informasi yang bervariasi dalam jumlah yang banyak. Oleh karena itu, ada tiga hal yang dapat ditempuh dalam memelihara aktivitas mengingat, yaitu: memperhatikan setiap informasi yang diterima, menahan daya ingat dengan jalan mengulang informasi secara terus- menerus dan mentransfer informasi dalam ingatan dalam jangka waktu yang lama.

\section{Pengertian emosi}

Emosi berasal dari kata "movere" yang berarti menggerakkan atau bergerak menjauh. Dalam bahasa Inggris dikenal dengan istilah "emotion" yang berarti emosi atau perasaan.

Emosi merupakan penyesuaian organis yang timbul secara otomatis pada manusia dalam menghadapi situasi-situasi tertentu. 
Jadi, emosi timbul disebabkan oleh adanya gejolak psikis. Gejalanya bisa diperoleh dari faktor dasar (watak, karakter, hereditas) atau karena berbarengan dengan bertambahnya usia dan pengalaman atau lewat proses kondisioning dan diferensiasi aneka macam emosi itu bisa di kenal dan dirumuskan hanya dalam hubungannya dengan situasi di mana emosi itu timbul. Misalnya, emosi dan cinta timbul karena situasi yang dihadapi merangsang selera simpati, emosi takut, timbul karena situasi yang dihadapi menyentuh rasa seni yang terdalam dan seterusnya.

Oleh beberapa ahli, emosi ini dikelompokkan sebagai berikut:

- Amarah, seperti: bringas, mengamuk, benci, marah besar, jengkel, kesal hati, terganggu, rasa sakit, berang, tersinggung, bermusuhan, tindak kekerasan

- Kesediaan, seperti: pedih, sedih, muram, suram, melankolis, mengasihani diri, kesepian, ditolak, putus asa, dan kalau menjadi patologi menjadi depresi berat

- Rasa takut, seperti: cemas, gugup, khawatir, was-was, perasaan takut sekali, waspada, sedih, tidak tenang, ngeri, kecut, jika jadi patologi, pabio dan panik

- Kenikmatan, seperti: bahagia, gembira, puas, riang, senang, terhibur, bangga, kenikmatan indrawi, takjub, rasa terpesona, rasa puas, rasa terpenuhi, kegirangan luar biasa, senang, senang sekali.

- Cinta, seperti: penerimaan, persahabatan, kepercayaan, kebaikan hati, rasa dekat, bakti, hormat, kasmaran, kasih.

- Terkejut, seperti : terkejut, terkesiap, takjub, terpanah.

- Jengkel, seperti: hina, jijik, muak, mual, benci, tidak suka, mau muntah

- Malu, seperti: rasa bersalah, malu, kesal, sesal, hina, aib dan hancur lebur.

Meskipun pengelompokan di atas belum menggambarkan secara sempurna tentang emosi, dapat memberikan gambaran tentang ruang lingkup emosi tersebut. Dari pengelompokan di atas dapat dikategorikan empat emosi inti, yaitu: takut, marah, sedih, dan senang. Dengan demikian, emosi pada dasarnya merupakan dorongan 
untuk bertindak, keadaan atau reaksi psikologis dan fisiologis individu dalam merespons keadaan-keadaan tertentu.

\section{APLIKASI DAKWAH DALAM MENGEMBANGKAN KOGNISI AUDIENS}

Manusia sebagai sasaran dakwah (audiens) adalah makhluk yang memiliki kesadaran dan ia sadar sebagai makhluk yang mempunyai kesadaran, tetapi justru kesadaran akan membawa manusia ke dalam banyak misteri dan teka - teki kehidupan. Sudah banyak analisis, hipotesis dan sintesis, tetapi belum juga ada kejelasan yang universal tentang apa dan siapa sebenarnya hakikat manusia. Rupanya manusia selalu menjadi sesuatu yang keramat, unik dan menarik, langka tapi nyata, menjadi barang aneh bagi dirinya sendiri dan senantiasa merangsang bagi penyelidikan. Tak habishabisnya penelitian dilakukan tentang keberadaan manusia di dunia ini mengenai hidup dan matinya, dan last but not least tentang tingkah laku psikisnya dan tingkah laku rohaninya.

Banyak pola yang di hayati orang untuk mencari metode kepada penyelidikan, mulai dari ilmu pengetahuan alam, ilmu-ilmu sosial, filsafat, ilmu jiwa sampai dunia kepercayaan dengan bermacam variasi dan fantasinya dan tidak ketinggalan ilmu agama dan ilmu dakwah yang kemudian dimanifestasikan ke dalam tingkah lakunya seharihari dengan berbagai sifat dan sikapnya. Selanjutnya manusia selalu diperhadapkan dengan berbagai problema kehidupan, baik secara fisik maupun rohani.

Dalam posisi yang demikian itulah, manusia memerlukan bimbingan spritual atau dakwah Islam. Pendekatan dakwah yang baik adalah dakwah yang diterapkan secara efektif dalam hal metode, materi, media, dan faktor-faktor lainnya.

Salah satu aspek individu yang perlu mendapatkan bimbingan adalah pikiran . berpikir disebut juga gejala kognisi atau gejala cipta. Berpikir adalah proses kerja pikiran. Berpikir merupakan gejala jiwa yang mengatur dan mengontrol segala perilaku manusia. Berfungsi untuk mengenal, mencipta atau memecahkan problema. Dalam kerjanya, berpikir menggunakan akal (intelegensia) yang berlokasi pada otak sebagai tempat singgah lalu lintas proses berpikir. Ada tingkatan berpikir, yaitu: berpikir konkret, berpikir skematis, dan 
berpikir abstrak. Dengan berpikir, manusia memperoleh pengetahuan, pengertian dan ilmu pengetahuan yang bertujuan untuk mencapai kebenaran. Di saat manusia melakukan tugas berpikirnya, terjadilah dinamika gerak yang disebut tingkah laku (Kafie, 1993:51).

Untuk mengarahkan tingkah laku audiens berdasarkan pikiran - pikiran yang baik, maka seorang juru dakwah (mubaligh) haruslah bersifat edukatif (mendidik). Mendidik dalam pengertian dakwah adalah melakukan proses bimbingan dengan sengaja dan terusmenerus, selama proses perkembangan pribadi yang terjadi pada seseorang. Bimbingan dakwah berarti suatu proses aktivitas yang bertujuan agar tingkah laku audiens mengalami perubahan-perubahan sesuai dengan cita-cita dakwah tersebut.

Seorang juru dakwah seyogyanya memberikan bimbingan atau pesan-pesan dakwah berdasarkan perkembangan psikis. Seorang mubaligh yang baik bukan hanya membawakan pengetahuannya tentang materi dakwah yang disampaikannya, tetapi juga membawakan dirinya sendiri dalam keseluruhan (konstitusi jasmaniah, status emosi, sikap, minat dan sebagainya). Mubaligh hendaknya mempelajari dengan seksama agar mengenal dan memahami dasar-dasar tingkah laku dan reaksi audiensnya yang berbeda - beda dalam proses dakwah yang dilakukan. Oleh karena itu, dalam membina pikiran atau proses kognisi audiens maka juru dakwah dapat menempuh langkah-langkah sebagai berikut:

- membuka jalan dan memudahkan terjadinya perubahan-perubahan tingkah laku audiens, seperti apa yang diharapkan dalam tujuan dakwah, sehingga audiens dapat melakukan respons yang diubah dan disesuaikan dengan tuntunan lingkungan.

- mengadakan interaksi dominan (bilamana juru dakwah sendiri mendorong, mengarahkan audies untuk berbuat, merasakan atau berpikir sesuai dengan kehendaknya) dan sosial integratif (bilamana juru dakwah memberikan fasilitas dan perkenan bagi audien untuk mencari sendiri apa yang dicari, merasakan, memikirkan dan melakukan sendiri sesuai dengan kesanggupan dan kemampuannya). Interaksi itu dapat bersifat penilaian, berbentuk 
keputusan mengenai seluruh situasi yang dihadapi dalam proses dakwah dengan menerapkan berbagai prinsip psikologi.

Dengan demikian, juru dakwah memiliki tugas dan memikul tangung jawab besar terhadap perkembangan sikap apresiasi dan sasaran sesuai dengan kemampuan audiens masing-masing.

Untuk melakukan hal di atas maka materi dakwah harus terlebih dahulu diadakan pemilihan dan rincian serta pernyataan secara seksama agar dapat merangsang kepuasan batin audiens. Untuk itu, materi dakwah harus disajikan sesuai dengan aspek-aspek dalam kehidupan sehari-hari, perbedaan cara tiap-tiap individu dan memahaminya, diselaraskan dengan tujuan yang hendak dicapai, dan disajikan secara metodologis.

Dalam hal metode dakwah, juru dakwah harus menguasai bermacam-macam metode dan terampil menggunakannya, komunikatif dan memperhitungkan kendala-kendala atau hambatanhambatan psikologis dalam penerapan suatu metode.

Aspek kognisi sebagai salah satu faktor yang sangat mempengaruhi sikap audiens terhadap ajaran-ajaran Islam, perlu selalu dipandu oleh proses dakwah. Idealnya adalah apabila pikiranpikiran yang baik yang telah ditanamkan oleh dakwah tersebut dapat diimplementasikan dalam berbagai aspek kehidupan sosial oleh audiens. Artinya, suatu masyarakat yang memakai Islam sebagai identitas, seharusnya lebih dinamis dan maju dalam kehidupan sosialnya. Harus ada korelasi yang nyata antara ketakwaan dan kehidupan sosial. Di sinilah peranan dakwah memberikan hubungan kepada audiens sehingga mereka dapat menyesuaikan diri dengan lingkungan sekitarnya.

Audiens dengan kemampuan psikologis dan fisiologis (jasmaniah) tidak bisa berkembang dengan normal tetapi dengan adanya proses interaksi dengan lingkungan hidup sekitar, baik berupa kelompok sosial maupunn kultural mampu berupa lingkungan ekologis (alamiah) di mana anggota masyarakat lainnya hidup berkembang dalam menghayati lingkungan hidupnya, audiens memfungsikan kemampuan persepsinya (perceptional capacity) yang 
tidak sama lagi pada setiap individu. Tanggapan (persepsi) terhadap lingkungan tersebut berbeda-beda bagi setiap audiens menurut pengalamannya (Arifin, 1993:109-110).

Dalam menghadapi audiens yang berbeda-beda tingkat pengetahuan dan pikirannya, juru dakwah dituntut untuk melakukan pendekatan-pendekatan secara individual-psikologis sehingga dapat memberikan wawasan dan sistem dengan ciri-ciri kemampuan kejiwaan audiens tersebut. Untuk itu, pesan-pesan dakwah yang disampaikan hendaknya sesuai dengan maksud dan sabda Nabi Muhammad saw.: "Berbicaralah dengan manusia sesuai dengan tingkat akal pikirannya/kecerdasannya" (Hadis).

Untuk mencapai maksud di atas maka mubaligh harus memiliki kompetensi, yaitu sejumlah pemahaman, pengetahuan, penghayatan, dan perilaku serta keterampilan tertentu yang memadai. Kompetensi seorang mubaligh adalah suatu penggambaran ideal dan sekaligus target yang harus mereka peduli, kompetensi tersebut meliputi: pertama, kompetensi substantif berupa: pemahaman agama Islam secara cukup, tepat dan benar, pemahaman hakikat gerakan dakwah, memiliki akhlak yang terpuji, mengetahui perkembangan umum yang relatif luas mencintai audiens, mengenal kondisi lingkungan dengan baik, mempunyai rasa ikhlas karena Allah; dan kedua kompetensi metodologis, yaitu mampu membuat perencanaan dakwah yang akan dilakukan dan sekaligus mampu melaksanakan perencanaan tersebut (Mulkhan, 1996:237-240).

\section{APLIKASI DAKWAH DALAM MENGEMBANGKAN EMOSI AUDEINS}

Emosi tidak dapat dimatikan melainkan disalurkan secara baik dan sering pula emosi didasari oleh motivasi tertentu. Jadi, emosi berhubungan dengan kehendak. Motif adalah sesuatu yang abstrak, yaitu suatu dorongan dan kekuatan dari dalam diri manusia sebagai penuntun tingkah lakunya untuk menyesuaikan diri dengan lingkunganya agar mencapai apa yang menjadi tujuan sesuai dengan yang dikehendaki. Hal inilah yang disebut "hati" dalam konsep ajaran Islam. Seluruh tingkah laku atau amal perbuatan manusia menurut 
Islam, bersumber dari dalam hati, sesuai dengan sabda Rasulullah saw.: "Sesungguhnya di dalam tubuh itu ada segumpal daging. Apabila ia baik maka baiklah seluruh amal (tingkah lakunya) dan apabila ia rusak maka rusaklah seluruh amal (tingkah lakunya). Ketahuilah bahwa segumpal daging itu ialah hati" (Hadis Riwayat Bukhari-Muslim).

Pada manusia terdapat bermacam-macam variabel emosi yang dapat muncul setiap saat. Ini menyangkut hubungan variabel emosi yang dihayati seseorang dengan nilai keseluruhan makna kehidupan. Hal-hal yang memberikan makna pada hidup merupakan sesuatu yang bernilai untuk dijadikan tujuan. Apabila suatu penghayatan mempunyai arti yang mendalam bagi seseorang maka penghayatan itu akan mempengaruhi variabel motivasi dan emosi dalam kehidupannya. Nilai tertinggi dalam bermotivasi adalah tujuan hidup manusia yang dalam Islam berupa konsep ibadah. Ibadah adalah seluruh aktivitas manusia lahir - batin, termasuk tidurnya yang diniatkan karena Allah semata. Konsep ibadah adalah kewajiban tunggal bagi manusia karena ia merupakan satu-satunya medan untuk beramal dan mengumpulkan nilai-nilai (Q.S Al-Dhariyât [51]:56).

Dakwah senantiasa berupaya untuk memasukkan konsep ibadah ini karena konsep ibadah membentuk motivasi, tingkah laku dan tujuan hidup manusia vans disebut taqwa Maka untuk mencapai tujuan takwa ini setiap tingkah laku harus senantiasa dilatarbelakangi motif (niat) ikhlas karena Allah semata (Q.S Al-Bayyinah [58]:5).

Juru dakwah sebagai motivator harus mengerti bahwa emosi ini muncul sebagai latar belakang dan seluruh tingkah laku audiens yang timbul karena adanya dorongan kebutuhan yang muncul setiap saat. Dalam hal ini, juru dakwah diharapkan mampu pertama, memberikan motivasi dan dorongan-dorongan kepada audiens untuk bertingkah laku atau mengekspresikan emosinya dalam bingkai akhlakul karimah dan amal saleh dan kedua, senantiasa memenuhi tiga faktor dasar yang membentuk suatu lingkaran emosi, yaitu kebutuhan, tingkah laku, dan tujuan sehingga dapat memulihkan materi dakwah yang sesuai dan menerapkan metode yang memenuhi harapan. 
Materi dakwah harus dirancang sehingga dapat meningkatkan motivasi. Maksudnya, harus dijadikan sebagai kebutuhan hidup audiens agar mereka terdorong untuk bertingkah laku dan tingkah lakunya itu diarahkan untuk mencapai tujuan dakwah. Materi dakwah harus disajikan untuk dapat memenuhi kebutuhan rohaninya serta merumuskan kehendak emosinya.

Metode dakwah digunakan untuk kondisi internasional yang lebih bersifat psikologis dan sebagai alat kontrol dorongan-dorongan kehendak naluriah individual manusia yang bersifat destruktif, dengan cara memperhatikan bentuk pola tingkah laku yang bermacam-macam itu lalu dikembalikan pada dasar pokoknya, waktu kebutuhan akan hal psikis seperti: kasih sayang, rasa aman. kebebasan, rasa harga diri, rasa sosial dan sebagainya atau dihadapkan kepada norma-norma yang berlaku di mana kekuatannya dapat mengarahkan jalanya tingkah laku ke arah yang konstruktif.

Selain itu, dengan memilih materi yang cocok maka metode harus dapat menghadapi secara wajar setiap persepsi individual manusia terhadap tugas-tugas yang sudah menjadi bidang atau pikirannya sendiri dengan berlandaskan Tut Wuri Handyani. Kebutuhan psikis yang paling menonjol pada diri manusia adalah jaminan rasa aman dan perlindungan dari segala bentuk ancaman terhadap integritas dan stabilitas hidupnya, sehingga adanya jaminan dan perlindungan itu akan sangat mempengaruhi dorongan-dorongan keinginan kepada hal-hal yang baru, kepada kepercayaan dan konformitas, dorongan untuk maju dan motivasi sehingga dengan mudah proses dakwah dapat dilangsungkan, materi dakwah mudah diterima bahkan menaruh simpati yang pada gilirannya akan mudah mengaktualisasikan pesan-pesan dakwah ke dalam perilaku pribadinya.

Pada hakekatnya manusia mempunyai kemampuan dasar yang sama dan mempunyai kebutuhan yang sama. Secara biologis/psikis manusia ingin mempertahankan dan melangsungkan kehidupannya. Oleh karena itu, manusia membutkan makanan dan minuman serta kebutuhan fisik lainnya. Manusia mempunyai kecenderungan rasa senang dan ingin menyalurkan kesenangannya, mempunyai rasa puas dan ingin akan kepuasan, mempunyai segala macam keinginan dan menyelamatkan semua keinginannya. karena manusia mempunyai 
emosi. Di sinilah dakwah islamiah berperan di dalam mengajak manusia untuk menyadari hak dan kewajibannya sebagai manusia sehingga tampaklah adanya ukhuwah insâniyyah (persaudaraan sesama manusia) karena dakwah itu dalam satu segi merupakan tugas kemanusiaan, yaitu mamanusiakan manusia (Anshari, 1993:100).

Untuk mendukung dan mempermantap dorongan bertingkah laku yang islami sesuai dengan tujuan dakwah maka dapat pula diterapkan pendekatan dakwah secara sugestif dan persuasif

Peranan sugestif dan pembentukan norma-norma dan pedomanpedoman tingkah laku sangatlah besar sebab pada umumnya di antara pedoman tingkah laku itu, banyak yang bersumber dari adat kebiasaan yang diambil dengan begitu saja tanpa pertimbangan lebih lanjut, baik dari orang tua, guru, pemimpin maupun orang lain di lingkunganya. Hal ini disebabkan oleh kehidupan zaman modern yang sudah demikian kompleks sehingga mengambil atau meniru pandangan dan tingkah laku orang lain lebih mudah mereka lakukan. Jadi, sugesti dapat dirumuskan sebagai suatu proses di mana seseorang menerima suatu cara atau pedoman tingkah lakunya dari orang lain yang dapat memanfaatkan nilai-nilai Islam.

Di dalam kehidupan sosial modern, faktor sugesti banyak digunakan, yaitu dalam iklan atau reklame dengan menggunakan metode psikologis sebagai cara pendekatannya. Dalam situasi kompleks atau perasaan tegang, kelelahan fisik, dan mental, sugesti akan sangat mudah diterima oleh orang. Sebab itu, kendali manusia modern mempunyai orientasi berpikir secara logis-rasional tetapi karena dalam lingkungan kehidupan modem orang di-expose dengan banyak rangsangan dalani dosis yang tinggi, seringkali mereka mengalami banyak problema dan konflik batin. Rangsangan di sekitarnya sudah menyebabkan manusia modern dihadapkan kepada berbagai alternatif yang membutuhkan jalan keluar secara tepat.

Dalam kondisi seperti itu, tidak jarang mereka berkonsultasi kepada dukun-dukun jahat yang menurut pandangannya mempunyai otoritas dan kharisma tersendiri dalam membantu memecahkan persoalannya. Dengan demikian, dakwah harus tampil memberikan. bimbingan rohani, ketenangan batin, dan paket-paket dakwah lainnya yang dapat mengantarkan mereka kepada jalan kebenaran dan kebahagiaan. 
Juru dakwah sebagai sugestif mempunyai tugas dan tanggung jawab untuk dapat memanfaatkan situasi-situasi dan menggunakan kondisi-kondisi yang tepat untuk menimbulkan sugesti audiens agar pikiran, perasaan, emosi dan kehendak mereka bisa terpengaruh dengan keyakinan terhadap apa yang menjadi tujuan dakwah. Materi dakwah dapat dipilih secara tepat dengan memanfaatkan sugesti untuk menyembuhkan gejala-gejala neurotik, khususnya gejala-gejala histeris dan bisa mengubah sikap atau memelihara suatu keyakinan audiens yang sesuai dengan tujuan dakwah. Metode yang digunakan sebagai cara bagaimana menanamkan sugesti, artinya untuk mengugah minat dan kesadaran bahwa suatu masalah memiliki sangkut-paut dengan dirinya maka metode sugesti yang positif adalah penekanan usaha untuk tetap memperkaya jalur interaksi mereka dan Tuhannya (iman), memperkuat keinginan untuk aktif beribadah (amal) dan memelihara nilai - nilai moral (akhlak) dalam diri audiens dalam rangka membentuk intra-sugestif (sugesti yang terjadi dalam diri) atau inter-sugestif (sugesti yang terjadi dari orang lain).

Secara persuasif emosi audiens dapat diarahkan sesuai dengan tujuan dakwah melalui metode-metode di bawah ini:

- Metode sosialis, yaitu penyajian pesan dakwah dengan jalan menumpangkan pada suatu peristiwa yang sedang menarik perhatian dan minat audiens.

- Metode integrasi, yaitu kemampuan untuk menyatakan diri dengan audiens dalam arti menyalurkan diri secara komunikatif, sehingga tampak menjadi satu. atau mengandung arti kebersamaan dan senasib sepenanggungan dengan audiens baik dilakukan secara verbal maupun non-verbal (dakwah bilhal).

- Metode psy-off dan fear-arousing, yaitu kegiatan mempengaruhi. orang lain dengan jalan melukiskan hal-hal yang menggembirakan dan menyenangkan perasaannya atau memberi harapan atau sebaliknya dengan. menggunakan ha-hal- yang menakutkan atau menyajikan konsekuensinya yang buruk dan tidak menyenangkan perasaan.

- Metode icing, yaitu menjadikan indah sesuatu sehingga menarik bagi yang menerimanya. Metode icing disebut juga metode memanis-maniskan atau menata pesan-pesan dakwah dengan 
emotional appeal sedemikian rupa sehingga audiens menjadi lebih tertarik.

Metode-metode tersebut di atas dapat digunakan dalam proses pelaksanaan dakwah secara efektif. Juru dakwah sebagai persuader harus mampu berkomunikasi atau melakukan proses interaksi antarrelasi dan proses saling mempengaruhi. Dakwah merupakan usaha mempengaruhi manusia menghindari yang munkar dan melakukan yang makruf, dari kondisi ragu menjadi mantap dan yakin. Dengan demikian, materi dakwah harus ditata direncanakan dan dipilih secara selektif kemudian dievaluasi dalam sumbangannya dengan audiens, kemudian disampaikan dengan menggunakan metode asosiatif, integratif dan teknis lainnya yang tujuan akhirnya adalah efek yang mampu mengubah tingkah laku dan sikap hidup audiens agar tetap berada dalam kedaan stabil sebagaimana yang dikehendaki oleh tujuan dakwah (Kafie, 1993:78).

Persuasi dalam dakwah adalah seni dan jumlah tentang menghimbau secara ekstralogis untuk menjamin keputusan yang diinginkan dengan prinsip-prinsip argumentatif. Walaupun komunikasi persuasif ada kesamaannya dalam membujuk dengan propaganda namun berbeda dengan dakwah, Perbedaannya tidak terletak dalam bagaimana cara membujuknya dan bukan dalam isi pesan yang disampaikan saja, melainkan dalam hubungan secara terus menerus dengan audiens untuk memberikan bimbingan demi kebahagiaan audiens.

\section{PENUTUP}

Dari uraian di atas dapat dikemukakan bahwa dakwah merupakan manifestasi teologi yang diwujudkan dalam bentuk ihtiar orang-orang Islam dalam berbagi aspek kehidupan untuk membimbing umat manusia sehingga dapat memperoleh kebahagiaan di dunia dan di akhirat. Kognisi dan emosi merupakan potensi yang dimiliki oleh setiap audiens sehingga perlu diarahkan melalui kegiatan dakwah sehingga mereka dapat memiliki tingkah laku yang islami. Efektivitas dakwah tercermin pada sejauh mana audiens dapat menerima menghayati dan mengamalkan ajaran - ajaran Islam, baik 
dalam tataran individu maupun dalam tataran masyarakat untuk mengembangkan potensi kognisi audiens. Oleh karena itu, aktivitas dakwah harus ditata secara baik, meliputi: kompetensi juru dakwah , materi dakwah yang relevan dengan kebutuhan audiens, dan metode dakwah yang tepat. Jika ketiga unsur ini dapat diterapkan secara dialektif - fungsional maka tercapailah tujuan-tujuan dakwah yang diharapkan.

\section{DAFTAR PUSTAKA}

Ahmad, Amrullah (Ed.). 1983. Dakwah Islam dan Perubahan Sosial Cet. I. Yogyakarta: Prima Duta.

Anshari, M., Hafi, 1993. Pemahaman dan Pengamatan Dakwah: Pedoman untuk Mujahid Dakwah. Cet. I. Surabaya: Al-Ikhlas.

Arifin, M., 1993. Psikologi Dakwah: Suatu Pengantar Studi. Cet. II. Jakarta: Bumi Aksara.

Hasan, Chalidjah. 1994. Dimensi - Dimensi Psikologi. Cet. I. Surabaya: AlIkhlas

Hasjmy. A.. 1994. Dustur Dakwah menurut Al-Qur'an. Cet. III. Jakarta: Bulan Bintang.

Kafie, Jamaluddin. 1993. Psikologi Dakwah: Suatu Pengantar Studi Cet. II. Surabaya: Indah.

Mulkhan, Abdul Munir. 1996. Ideologisasi Gerakan Dakwah: Episod Kehidupan M. Natsir dan Azhar Basyir. Cet. I.. Yogyakarta: Sipress.

Syukur, Asmuni. 1983. Dasar-Dasar Strategi Dakwah Islam. Surabaya: AlIkhlas. 